\title{
JTE
}

\section{Journal of Teaching English}

Volume 5 No. 3, 2020

e-ISSN: 2548-6810

\section{THE EFFECT OF BLINDFOLD GAME ON STUDENTS' VOCABULARY ACHIEVEMENT AT SMP NEGERI 13 KENDARI}

\author{
Andi An-Nisaa Arfin ${ }^{1}$, Kamaluddin ${ }^{2}$, Wa Ode Fatmawati ${ }^{3}$ \\ nisaaandi@gmail.com \\ ${ }^{1}$ Halu Oleo University, Indonesia
}

\begin{tabular}{l}
\multicolumn{1}{c}{ ARTICLE INFO } \\
\hline Keywords: \\
Blindfold Game, \\
Vocabulary \\
Achievement, \\
How to cite: \\
DOI:
\end{tabular}

\begin{abstract}
The purpose of conducting this research is to examine the difference NGain scores between students who learn vocabulary with Blindfold Game and students who learn vocabulary without Blindfold Game at the first year students of SMP Negeri 13 Kendari. The samples of this research are the first grade four (VII-4) and the first grade three (VII-3) which consists of 27 students for each class. This research is conducted in comparison research design that consists of experimental class (VII-4) and controll class (VII-3). The data of this research are collected by giving pre-test and post-test in two classes (VII-4 \& VII-3). The result shows that there is an improvement of the students' vocabulary achievement. Independent samples t-test shows that, there is a significant difference in the Ngain scores for experimental class $(\mathrm{M}=60.08, \mathrm{SD}=$ $9.36)$ and controll class $(\mathrm{M}=20.41, \mathrm{SD}=14.56), \mathrm{t}(52)=$ 11.904, $\mathrm{p}(0.000)<0.05$. Therefore, it can be concluded that the value of Sig (2 tailed) is lower than the significance a value $(0.000<0.05)$. In other words, alternative hypothesis $\left(\mathrm{H}_{1}\right)$ is accepted and the null hypothesis $\left(\mathrm{H}_{0}\right)$ is rejected. It means that the Blindfold game can enrich students' vocabulary achievement for Junior High School Student.
\end{abstract}

\section{Introduction}

In English, vocabulary is very critical. Hatch and Brown (1995) defined vocabulary as a tool or a set of words for a particular Language or a list or set of word that individuals speakers of Language might use. While according to Roger (1980), vocabularies are: (1). The vocabulary is an alphabetical list of words that are often described or translated. (2). All the words Language. (3). Specialized expression indigenous to a praticular fields, subject, trade, or subculture. For every competence in English, vocabulary needs more attention to be paid to teaching and learning. Vocabulary is more important 
than grammar as the basic of Language. In order to get the other skills of English such as Writing, Reading, Listening, and Speaking, Vocabulary is the basic skill to get them. We can not master the other English skills without mastering the vocabulary first. Because of that, some of English teachers try to enrich student's vocabulary by using various teaching strategies.

Vocabulary is not something to be achieved easily, it needs a time to expand and deepen it. Learning and teaching vocabulary is not just about how to find the words in the dictionary to get the meaning of words or apply a word in a sentence. Vocabulary needs to apply specifically through word learning strategies as a tool to make vocabulary becomes more specific to be learned and taught.

According to the explanation above, we can conclude that one of the learning strategies to teach vocabulary that have been presented in this era is learning through playing game. Kozma (1991) said that student's motivation to study, and take an active role in learning process can be improved by a good leaning media. Hadfield (2003) in Sirbu (2017) defines game as an activity with rules, a goal, and element of fun. Game as a media to train vocabulary can be an answer of the big problem that students faced in English learning process. In sum, Making the learning process become more interesting, entertaining, and challenging for the students are the purposes of the using game as a tool to enrich students' vocabulary.

Blindfold game is one of the game that teacher can use as a media to teach vocabulary for the students. Vocabulary games incorporate real-world meaning into the classroom and promote the dynamic, communicative use of English by students (Huyen and Nga, 2003). According to them, game vocabulary can bring students to learn vocabulary in the real life and it can make them easy to learn it. Blindfold game is an interesting and funny game to teach and learn vocabulary. Through this game, students will learn vocabulary within a group, next they will try to guess something with close eyes one by one. In result, students will feel challenging to describe and help each other to finish the game. Relating to the previous background, the researcher formulated the research question as follow Is there any significant difference between students who learn vocabulary with Blindfold Game and students who learn vocabulary without Blindfold Game?

\section{Methods}

The design of this research was Comparison Design that involving two groups of classes. One group treated as the experimental class and other 
group treated as the control class. In experimental class, researcher used

Independent Samples Test

Blindfold Game in teaching vocabulary while in control class researcher didn't use Blindfold Game in learning process. The researcher used pre-test and post-test design in both experimental and controll class. The aim was to find out of the using of Blindfold game in teaching students' vocabulary. The study has conducted on July $15^{\text {th }} 2019$ until July 30th 2019. It was done at SMPN 13 Kendari with students of Class VII-3 and VII-4 as samples.

The study used pre-test and post-test design in both experimental and controll class as the instrument for the sample to measure their vocabulary achivement. And for treatments, this study used some of descriptive texts which similar to Blindfold Game. The descriptive texts is the written form, while Blindfold game is the spoken form. The data of this study was analyzed quantitatively and was interpreted by using descriptive and inferential statistic. Descriptive statistic was used to know the different results that exist in student pre tests and post tests before and after the treatment. Meanwhile, inferential statistic was used to test the hypothesis by using Independent Sample T-test in SPSS Application version 16.0. It was to know the significance difference of Blindfold Game on Students' Vocabulary Achievement at SMPN 13 Kendari.

\section{Findings}




\begin{tabular}{|c|c|c|c|c|c|c|c|c|c|c|}
\hline & & \multicolumn{2}{|c|}{$\begin{array}{l}\text { Levene's Test for } \\
\text { Equality of } \\
\text { Variances }\end{array}$} & \multicolumn{7}{|c|}{ t-test for Equality of Means } \\
\hline & & \multirow[b]{2}{*}{$\mathrm{F}$} & \multirow[b]{2}{*}{ Sig. } & \multirow[b]{2}{*}{$\mathrm{t}$} & \multirow[b]{2}{*}{ df } & \multirow{2}{*}{$\begin{array}{l}\text { Sig. (2- } \\
\text { tailed) }\end{array}$} & \multirow{2}{*}{$\begin{array}{c}\text { Mean } \\
\text { Differenc } \\
\text { e }\end{array}$} & \multirow{2}{*}{$\begin{array}{c}\text { Std. Error } \\
\text { Differenc } \\
\mathrm{e}\end{array}$} & \multicolumn{2}{|c|}{$\begin{array}{l}95 \% \text { Confidence } \\
\text { Interval of the } \\
\text { Difference }\end{array}$} \\
\hline & & & & & & & & & Lower & Upper \\
\hline \multirow[t]{2}{*}{$\begin{array}{l}\text { NGain_P } \\
\text { ersen }\end{array}$} & $\begin{array}{l}\text { Equal variances } \\
\text { assumed }\end{array}$ & \multirow[t]{2}{*}{2.259} & \multirow[t]{2}{*}{.139} & $\begin{array}{r}11.90 \\
4\end{array}$ & 52 & .000 & 39.67288 & 3.33277 & 32.98518 & 46.36058 \\
\hline & $\begin{array}{l}\text { Equal variances } \\
\text { not assumed }\end{array}$ & & & $\begin{array}{r}11.90 \\
4\end{array}$ & $\begin{array}{r}44.34 \\
5\end{array}$ & .000 & 39.67288 & 3.33277 & 32.95760 & 46.38817 \\
\hline
\end{tabular}

An independent samples t-test was conducted on students' vocabulary test scores to examine whether there is a significant NGain difference between students taught using Blindfold Game (Experimental Class) and those who taught without using Blindfold Game (Controll Class). Independent samples t-test suggests that, there was a significant difference in the scores for experimental class $(\mathrm{M}=60.08, \mathrm{SD}=9.36)$ and controll class $(\mathrm{M}=20.41, \mathrm{SD}=$ $14.56), \mathrm{t}(52)=11.904, \mathrm{p}(0.000)<0.05$. Standard Deviation means the tests were distributed well if a group has a standard deviation value that near to 0 . The value of standard deviation of Experimental class is 9,36 and Controll Class is 14,56 . While to test the Hypothesis, we used $p$ value as the paramater. If $\mathrm{p}$ value $<0,05$ means that $\mathrm{H}_{1}$ will be accepted, but if $\mathrm{p}$ value $>0,05$ means that $\mathrm{H}_{0}$ will be rejected. Therefore, based on the table of hypotesis testing below, it can be concluded that there is significant difference in students' vocabulary. NGain scores for both groups. In other words, $\mathrm{H}_{0}$ is rejected while $\mathrm{H}_{1}$ is accepted.

\section{Discussion}


The result of this research shows that there is a significant effect of using Blindfold game in improving students' vocabulary achievement. It is proved by the data that have been explained in the previous part that students who taught vocabulary by using Blindfold Game (Experimental Class) has a significant improvement than students who taught vocabulary without using Blindfold Game (Controll Class).

Wright, Betteridge, and Buckby (2006) stated that the use of game in teaching vocabulary can be the alternative way in teaching. It can provide a conducive environment for students in order to make learning process more enjoyable. Game can create an enjoyable and entertaining activity in the class. It can be done if the activity is fun and not pressing the students. This was supported by Huyen and Nga (2003), according to them, game vocabulary can bring students to learn vocabulary in the real life and it can make them easy to learn it. It means that one of the ways that can be used to improve the students' vocabulary achievement is using game, for example Blindfold Game.

Blindfold Game is one of the media that could improve students' vocabulary (Andriyani,2017). She added that Blindfold Game is a practical exercise in verbal communication that used blindfold in the games. Blindfold game can create a conducive envioronment for the students. With this kind of situation, students will more likely to enjoy the learning process in the classroom. It will be more effective and have a better result to teach students in entertaining ways.

Using competitive game such as blindfold game in teaching vocabulary can motivate students. Based on Oxford Advanced Learner's Dictionary, a game is an activity which involves people or teams to compete against each other. This was supported by Andriyani (2017) who said that Blindfold can impel team members into working together more closely and blindfolds can make some teams building activities more memorable and wearing blindfolds can be fun. Blindfold game challenges students to compete each other. It also will create healthy competition. Students will be encouraged to win the game. They want to be the winner from the game. In that way, students will be more participate in learning process.

However, Blindfold game can create a conducive situation in the classroom. Students can learn in fun and interesting way. Teaching vocabulary by using blindfold game can help students in remembering vocabulary, requiring new vocabulary, enhancing their skills in describing a word, and make students enjoy the learning process. In the other words why blindfold game in increase students' vocabulary achievement is because the 
game can create an enjoyable class activity where students can remembering, requiring, enhancing, and understanding the meaning of the words all at the same time. It indirectly helps student in establishing vocabulary.

In applying Blindfold game, the researcher found some problems. They were limited time allocation and lack of vocabulary mastery. Limited time allocation could affect students' performance. The second was the lack of vocabulary. It could be seen when students were pretty difficult in describing a word. So, it spent much time. Besides, the students are still unfamiliar with this game so that sometimes they still confused when this game was applied.

In sum, based on the discussion abuve, Blindfold game is interesting media to practice vocabulary. It makes fun for students in teaching learning process and very useful provide students learning in context. In applying blindfold game is found that it is to be helpful and effective to increase students' vocabulary especially noun for first grade of SMP Negeri 13 Kendari especially in class VII-4 (experimental class). This research shows a positive effect in term of their vocabulary achievement especially noun.

\section{Conclusion and Recommendation}

Based on the findings, it could be concluded that applying blindfold gameis found to be helpful and effective to increase students' achievement especially noun at first grade SMP Negeri 13 Kendari at class VII-4 (experimental class). Before applying blindfold game in teaching vocabulary, the students had difficulty to memorize and require english words and less motivated in learning English vocabulary. After conducting the research, the students were more enthusiastic, active, and interesting to learn English vocabulary. Applying a game made the students didn't bored and also inceased their achievement expecially noun.

Furthermore, based on the result of the data analysis, there is an improvement of students' mean scores from pre test to post test from experimental class and controll class. And for the last test that is post test, mean score for the students in experimental class is higher than the students' in controll class, that is 79.64 for experimental class, and 58,43 for controll class.

Meanwhile, the test of hypothesis was using independent sample t-test was conducted to compare gain scores in experimental class and controll class. Independent sample t-test showed that a $0.000<0.05$, which can be intrepeted that $\mathrm{H} 0$ is rejected while $\mathrm{H} 1$ is accepted. Therefore, it can be concluded that there is significant difference in students' vocabulary NGain scores for both groups. 
In conclusion, Blindfold game is an alternative way that can be applied in enriching students' vocabulary achievement. It can be seen from the result of this study that students' scores in experimental class is higher than students' scores in controll class after being taught by using Blindfold game.

\section{References}

Huyen, N. T. T., and Nga, K. T. T. 2003. Learning Vocabulary through Games. Asian EFL Journal.

Wright, A., Betteridge, D., and Buckby, M. 2006. Games for Language Learning. Cambridge: Cambridge University Press.

Kozma, R.B. (1991). Learning with media. Review of Educational Research, 61(2), 179-212. Universifty of Michigan.

Andriyani, Rini. (2017). The implementation of blindfold game media to improve students' vocabulary mastery At mts nurul huda tanjung pura. State Islamic University of North Sumatera.

Sirbu, A. 2017. The Benefits of Games in Teaching Vocabulary to Primary Students. Journal of Innovation in Psychology, Education and Didactics. Vol. 21, No. 2. pp.137-148

Hatch, E. \& Brown, C. 91995). Vocabulary, Semantics, and Language Education. New york: Cambridge University Press.

Roger, H. (1980). The New Thesaurus. Boston: American Heritage Dictionary. 